\title{
IMPLEMENTASI E-COMMERCE UNTUK PENJUALAN PAKAIAN BEKAS PADA TOKO SECOND ORIGINAL
}

\author{
Muhammad Luthfan', Grace Gata ${ }^{2 *}$ \\ ${ }^{1,2}$ Fakultas Teknologi Informasi, Sistem Informasi, Universitas Budi Luhur, Jakarta, Indonesia \\ Email: ${ }^{1} 1612500635 @$ student.budiluhur.ac.id, ${ }^{2 *}$ grace.gata@budiluhur.ac.id \\ (*: coressponding author)
}

\begin{abstract}
Abstrak- Toko Second Original merupakan usaha perorangan yang bergerak dalam bidang penjualan pakaian-pakaian bekas. Saat ini kegiatan penjualan di Toko Second Original tidak menggunakan media online dalam penjualannya, serta belum tersedianya media promosi yang baik untuk memberikan informasi tentang produk yang dijual. Tujuan penulisan penelitian ini adalah menghasilkan website ecommerce penjulan Toko Second Original untuk memperluas jangkauan promosi penjualan. Maka dalam penelitian ini dibuat sebuah sistem informasi untuk menerapkan Sistem E-commerce agar dapat melakukan transaksi secara online. Pemodelan bisnis yang digunakan adalah Business Model Canvas (BMC) serta pengumpulan data dilakukan dengan cara observasi, wawancara, analisa dokumen, dan studi literatur. Dengan penerapan sistem ini maka Toko Second Original tidak lagi mengalami kesulitan dalam mempromosikan pakaian bekas yang dijual, menginformasikan, serta membantu customer dalam melakukan proses pemesanan dengan mudah dan cepat.
\end{abstract}

Kata Kunci: E-commerce, Sistem Informasi, Pakaian Bekas, Penjualan, SEO

\begin{abstract}
The Second Original store is an individual business that is engaged in the sale of used clothes. Currently sales activities at the Second Original Store do not use online media in their sales, and have not the availability of good promotional media to provide information about the products being sold. The purpose of writing this research is to produce an e-commerce website selling the Second Original Store to expand the reach of sales promotions. So in this study an information system was created to implement an E-commerce system in order to be able to conduct transactions online. The business modeling used is the Business Model Canvas (BMC) and data collection is done by means of observation, interviews, document analysis, and literature studies. With the implementation of this system, Second Original Stores no longer have difficulty in promoting used clothing that is sold, informing, and assisting customers in making the ordering process easily and quickly.
\end{abstract}

Keywords: E-commerce, Information System, Second hand clothes, Sales, SEO

\section{PENDAHULUAN}

Perubahan gaya hidup masyarakat dalam bisnis, terutama di masa pandemi yang berkepanjangan,telah membuat penggunaan teknologi informasi menjadi lebih maju dan cepat, dan sepanjang waktu dampaknya sudah mulai dirasakan dari segi pergerakan ekonomi sebagian besar masyarakat dari yang belum terbiasa menggunakan perangkat elektronik yang fungsinya menjadi modern dan cepat sehingga menimbulkan informasi dalam berbagai hal bidang, khususnya dengan membantu kegiatan terbatas menjadi lebih luas dan lebih cepat, bidang pendidikan, kesehatan, hiburan, sumber informasi, pekerjaan, bisnis dan komunikasi tanpa batas tempat dan waktu, kebutuhan mendapatkan informasi lebih cepat serta murah, menuntut para penyedia informasi untuk dapat memiliki sarana dengan fasilitas jaringan internet, sehingga jenis informasi yang dibutuhkan dapat dan cepat ditransmisikan oleh konsumen informasi. Penggunaan internet untuk kegiatan transaksi jual beli yang dikenal dengan sebagai perdagangan elektronik. Perdagangan Elektronik atau E-Commerce merupakan proses yang saling berinteraksi antara organisasi komersial dan konsumen, termasuk menggunakan Internet World Wide Web untuk menjual produk dan layanan kepada konsumen. Dalam dunia bisnis sub website berbentuk e-commerce sangat diperlukan untuk kegiatan perkembangan bisnis saat ini, dalam pengembangan usaha online karena dapat terdapat berbagai keunggulan yang dimiliki oleh e-commerce. Dengan kata lain konsumen dapat melakukan transaksi tanpa ke toko langsung sehingga dapat memilih, memesan, membeli dan dari sisi perusahaan dapat melakukan transaksi beroperasi selama 24 jam.[1] Toko Second Original merupakan sebuah usaha perorangan bergerak didalam bidang penjualan pakaian-pakaian second yang berlokasi di Jalan Inpres 7 No.19 RT 04/07, Kelurahan Larangan Utara, Kecamatan Larangan,Ciledug, Tangerang. Dalam kegiatan penjualan produk Toko Second Original masih menggunakan cara manual/offline sehingga pelanggan harus datang ke toko, dan pemasaran produk yang masih sangat kurang, karena tidak adanya media pemasaran secara online atau masih menggunakan media pemasaran melalui spanduk yang terdapat di depan toko saja. Berdasarkan permasalahan diatas Toko Second Original memerlukan sistem informasi online yang dapat memperlancar aktivitas jual beli sehingga data penjualan yang diolah menjadi lebih tepat serta penjualan produk mencapai target pasar dan pemasaran yang lebih luas tidak hanya di sekitar area toko tersebut dengan membuat website atau situs jual online. 
Menurut penelitian [2], melakukan hubungan dengan jaringan internet saat ini merupakan hal yang penting dikarenakan mempunyai ruang cakupan aktivitas yang luas tanpa adanya pembatasan. Keadaan yang dikuasai masyarakat di perkotaan khususnya penggunaan internet sangat tinggi, sekarang internet menjadi kebutuhan utama bagi kebanyakan orang. Toko Winata dalam pemasaran dan penjualan produk masih menggunakan metode konvensional. Meskipun usahanya berjalan dengan lancar tetapi pemilik merasakan kebutuhan inovasi sehingga untuk pengembangannya Toko Winata ke arah toko online. Dalam pembuatan website toko online ini menggunakan Bahasa pemodelan alur interaksi dibuat menampilkan konten, perilaku hubungan antar pengguna, serta pengaturan perilaku dari pengguna akhir aplikasi jual beli online.

\section{METODE PENELITIAN}

Metode penelitian adalah suatu kaidah langkah-langkah bagaimana suatu penelitian dilakukan secara bertahap[3]. Gambaran lain untuk penggunaan metode penelitian adalah usaha yang dilakukan seorang peneliti untuk menyatukan data penelitiannya, seperti salah satunya adalah wawancara, selanjutnya observasi, melakukan tes maupun pengumpulan dokumentasi dari bisnis yang berjalan[4],sedangkan metode penelitian mewujudkan suatu kegiatan untuk memperoleh pemecahan terhadap segala permasalahan[5].

\subsection{Kerangka Pemikiran}

Kerangka yang menggambar tahapan pemikiran dalam melakukan urutan yang akan dikerjakan. Pada tampilan gambar 1 terlihat kerangka menggambarkan pemikiran yang dilakukan dalam penelitian ini:

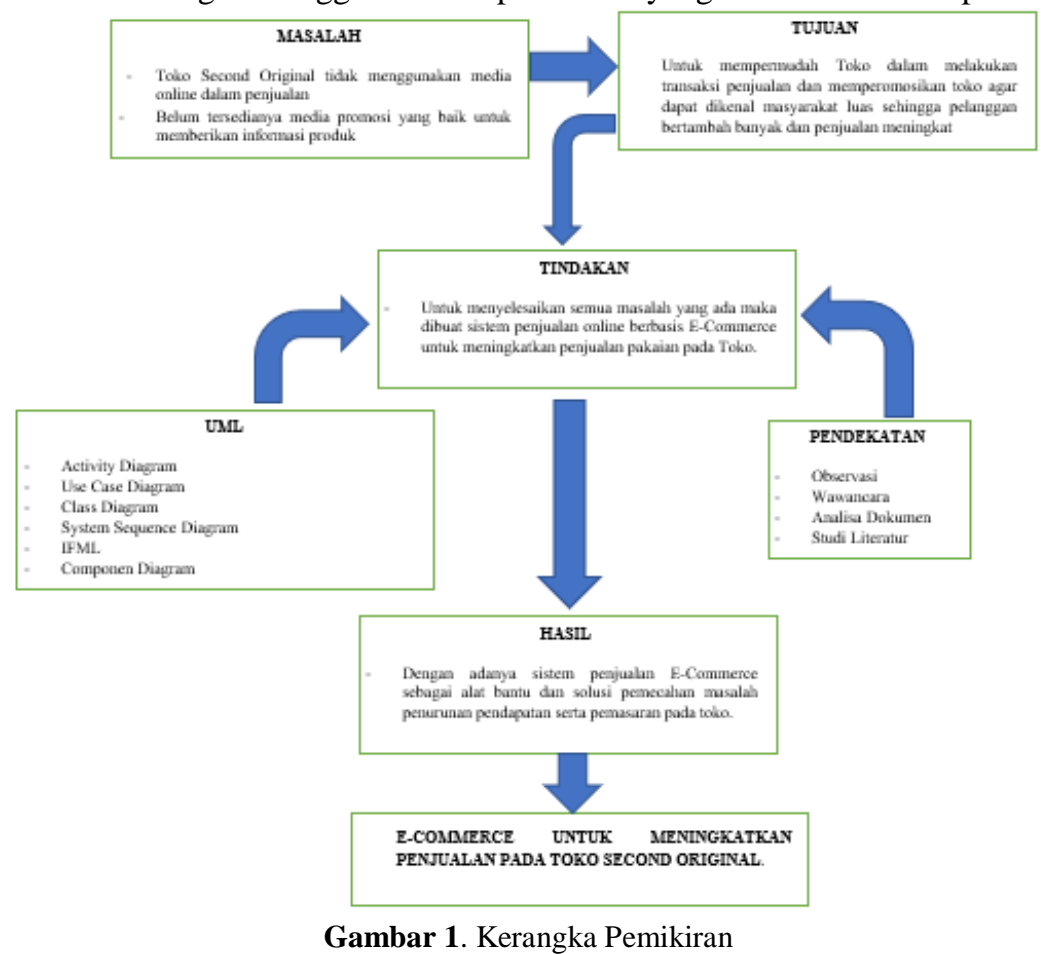

Untuk mempermudah dalam melakukan penjualan serta mempromosikan toko agar dapat dikenal masyarakat luas sehingga pelanggan bertambah dan penjualan meningkat, melakukan pendekatan dengan cara melakukan wawancara, observasi, dan dokumentasi. Keuntungan yang didapat adalah meningkatkan penjualan produk dan omset, Memudahkan pelanggan tanpa harus bertanya ketersediaan produk, Penjualan produk dapat meningkat dan mengurangi penumpukan barang digudang. Selanjutnya tindakan dalam menyelesaikan semua masalah yang ada maka dikerjakan suatu sistem penjualan online bersumber pada E-Commerce dengan menggunakan CMS Wordpress sebagai CMS yang paling sering digunakan untuk meningkatkan penjualan online[6]. Pada Gambar 1 menjelaskan kerangka pemikiran tahapan penyelesaian penelitian, Untuk analisa permasalahan pada Toko Second Original ini, maka dibutuhkan pendekatan pemecahan masalah menggunakan metode observasi, serta wawancara langsung ke pemilik, mengetahui data berjalan dan meneliti alur proses bisnis yang ada dengan membuat diagram-diagram. Untuk mengurai masalah yang dijumpai di Toko Second Original 
dibuatlah sebuah sistem jual beli menggunakan e-commerce dalam memperbanyak promosi penjualan barang di toko ini.

\subsection{Metode Pengumpulan Data}

Penelitian di toko ini dapat diselesaikan dengan metode yang digunakan yaitu: Observasi dengan memeriksa langsung serta melihat apa saja barang yang di jual pada Toko Second Original untuk mendapatkan informasi baik petunjuk yang diperlukan untuk data penelitian, melakukan wawancara yang berhubungan dengan kegiatan penjualan dilakukan dengan cara mengajukan sejumlah pertanyaan dari pewawancara untuk dijawab narasumber yaitu pemilik Toko Second Original untuk mendapatkan informasi. Dilanjutkan pengumpulan data dengan mencari informasi berdasarkan dokumentasi berjalan yang berhubungan dengan obyek penelitian, serta melakukan studi pustaka melalui jurnal dan buku yang ada di internet, serta melalui rujukan buku yang membahas hal yang sama.

\subsection{Metode Analisis dan Penggunaan Tools}

Analisis perancangan sistem ini dirancang secara detil sesuai hasil dari analisis sistem berjalan, menghasilkan gambaran dari sistem yang diusulkan, pada analisa ini tools yang diperlukan yaitu Class Diagram, Rancangan Layar, dan System Sequence Diagram. Kegiatan yang dibutuhkan yaitu menganalisis sistem yang berjalan dengan mempelajari serta mengetahui yang akan dilakukan sistem selama ini serta mengidentifikasi kebutuhan, dibutuhkan alat untuk mengambarkannya adalah Activity Diagram dan Use Case Diagram.

\subsection{Metode Perencanaan Bisnis}

Dalam penggambaran metode komponen perencanaan bisnis menggunakan Business Model Canvas untuk menjalankan lebih cepat proses analisis kekuatan serta kekurangan dari sisi bisnis. Dengan menggunakan Business Model Canvas dapat menentukan kekuatan bisnis dan kelemahannya, sehingga analisis kebutuhan dan pendapatan dapat diurai sesuai dengan penempatan komponen di Business Model Canvas. Berikut merupakan sembilan elemen Business Model Canvas, mempunyai komponen: Key Partners, Key Activities, Key Resources, Value Propositions, Customer Relationships, Customer Segments, Cost Structure.[7]

\subsection{Search Engine Optimization (SEO)}

Dalam perancangan website ini menggunakan search engine optimization untuk meningkatkan indeks serta peringkat hasil pencari dari sebuah mesin pencari guna memaksimalkan search engine optimization untuk keperluan promosi dan jumlah akses kunjungan pada website dan pembaruan foto agar ranking pencarian menjadi meningkat[8].

\section{HASIL DAN PEMBAHASAN}

\subsection{Business Model Canvas (BMC)}

Pembuatan proses sistem E-commerce penelitian di toko ini memakai metodologi BMC dalam menganalisis permasalahan dan kebutuhan pada Toko Second Original. Tujuan dari penelitian ini adalah dapat memetakan strategi berusaha yang sesuai kebutuhan dalam pengembangan usaha Toko Second Original dengan sistem Ecommerce, BMC yang terjadi pada Toko Second Original, yaitu: (1) Value Proposition, Merupakan elemen penting memberikan suatu produk maupun jasa yang dibuat menjadi menarik. Toko Second Original adalah toko yang menjual pakaian second. Value proposition yang sesuai dengan Toko Second Original adalah menjual produk second yang berkualitas dengan harga yang terjangkau dan pelanggan dapat membeli produk menggunakan instagram, website, atau bisa langsung datang ke toko. (2) Customer Segment, adalah titik fokus pasar yang menjadi keutamaaan Toko Second Original menjual produk. Target pelanggan di Toko Second Original adalah mahasiswa, anak-anak SMA, dan semua kalangan yang membutuhkan pakaian second branded. (3) Customer Relationship, Merupakan strategi bagaimana cara Toko Second Original mengiklankan dan meningkatkan hubungan dan mempertahankan pelanggan. Harapannya adalah agar pelanggan lebih loyal dan setia berbelanja yaitu dengan selalu mengadakan promo-promo dan produk-produk selalu dari brand-brand ternama. (4) Channels, Merupakan tentang alur sebuah produk dapat sampai ke pelanggan. Secara langsung menjual dengan menggunakan spanduk yang terdapat di toko, dan menjual melalui instagram. (5) Key Activities, Merupakan tentang kegiatan yang mendasar dalam bisnis. kegiatan utama menjadikan produk juga jasa. Penjualan berbagai produk merupakan suatu aktivitas utama dilakukan pada Toko Second Original dan membuat postingan semenarik mungkin di instagram agar pelanggan tertarik untuk membeli produk. (6) Key Resources, Merupakan 
tentang yang perlu disediakan suatu bisnis agar dapat berjalan. Resource ini didapat oleh usaha dapat juga berupa pinjaman. Mengenai yang dipunyai yaitu berupa toko, laptop, handphone, dan kendaraan. (7) Key Partnership, Merupakan tentang siapa saja menjadi penggerak jalannya kegiatan bisnis di Toko Second Original, dengan membuat hubungan baik dengan berbagai pihak tersebut seperti distributor pakaian-pakaian bekas/second yang menjadi distributor untuk Toko Second Original, kemudian bekerja sama dengan pihak ketiga, beberapa jasa kurir. Serta Niagahoster.id sebagai tempat yang menyediakan web yang digunakan dalam beberapa waktu. (8) Cost Structure, Merupakan tentang biaya diperlukan Toko Second Original dalam menjalankan kegiatan usaha. Ada beberapa biaya yang dikeluarkan yaitu: 1) Pembayaran sewa toko. 2) Pembelian stok. 3) Pembelian domain dan hosting. 4) Pembayaran listrik. 5) Biaya packing. 6) Internet. (9) Revenue Streams, Merupakan tentang pendapatan maupun penghasilan yang diperoleh Toko Second Original dalam mendapatkan keuntungan dari penjualan produk.

\subsection{Proses Bisnis Usulan}

\subsubsection{Proses Entry Product}

Admin login halaman back end website dan menambahkan produk dengan memilih menu produk kemudian klik tambah baru dan akan muncul halaman tambah baru produk, lalu admin mengisi halaman tambah baru produk. Setelah admin mengisi halaman tambah baru produk, admin mengklik tombol terbitkan untuk menerbitkan produk ke website Toko Second Original Seperti tergambar terlihat pada Gambar.2.

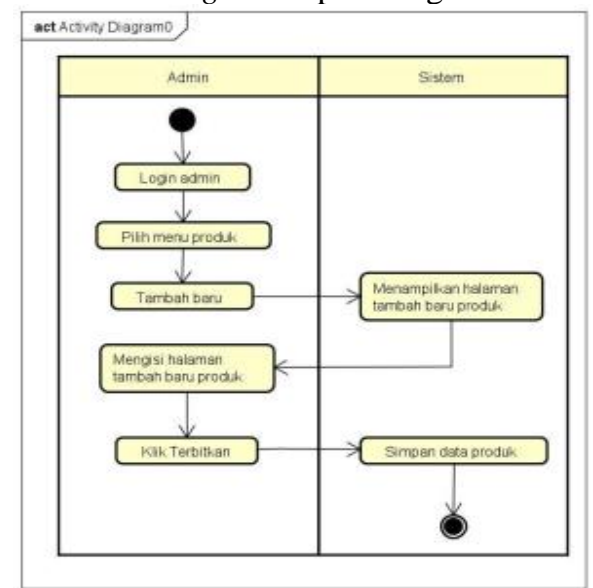

Gambar 2. Activity Diagram dalam Proses Penginputan Product

\subsubsection{Proses Pendaftaran}

Pelanggan ingin membeli produk dapat terlebih dahulu melakukan pendaftaran akun sehingga login ke website. Dengan langkah selanjutnya pelanggan dapat masuk ke website. Klik tombol My Account lalu pelanggan mengklik register lalu akan masuk ke halaman my account register dan pelanggan mengisi halaman register / daftar dan setelah selesai mengisi pelanggan klik tombol daftar maka sistem selanjutnya akan menerima masukan data pelanggan, lalu sistem akan melakukan pengiriman email ke pelanggan dan pelanggan mendapat email aktivasi. Seperti terlihat Gambar 3.

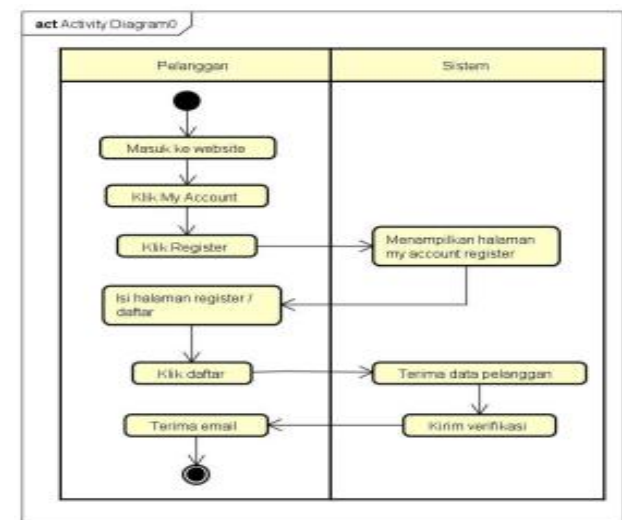

Gambar 3. Activity Diagram dalam Proses Pendaftaran 


\subsubsection{Proses Pemesanan}

Proses alur pemesanan produk dapat dilakukan dengan cara pelanggan menjelajahi website selanjutnya melakukan pemilihan produk yang ingin dibeli selanjutnya klik tombol tambahkan ke keranjang dan masuk ke halaman keranjang untuk mengisi jumlah produk yang dipesan, jika jumlah produk pesanan tidak diubah klik lanjutkan ke checkout. Jika jumlah produk pesanan diubah maka klik tombol perbaharui keranjang. Lalu sistem akan melakukan mengecekan apakah pelanggan sudah masuk login. Selanjutnya jika pelanggan tersebut sudah masuk login dan mempunyai akun, pelanggan mengisikan halaman checkout, jika pelanggan belum memiliki akun, maka sistem akan memberikan perintah harus login untuk bisa checkout, lalu pelanggan melakukan login terlebih dahulu, klik tombol buat pesanan. Pelanggan melakukan pengisian order, pelanggan akan menerima kiriman email invoice order langsung dari sistem. Seperti terlihat gambar 4.

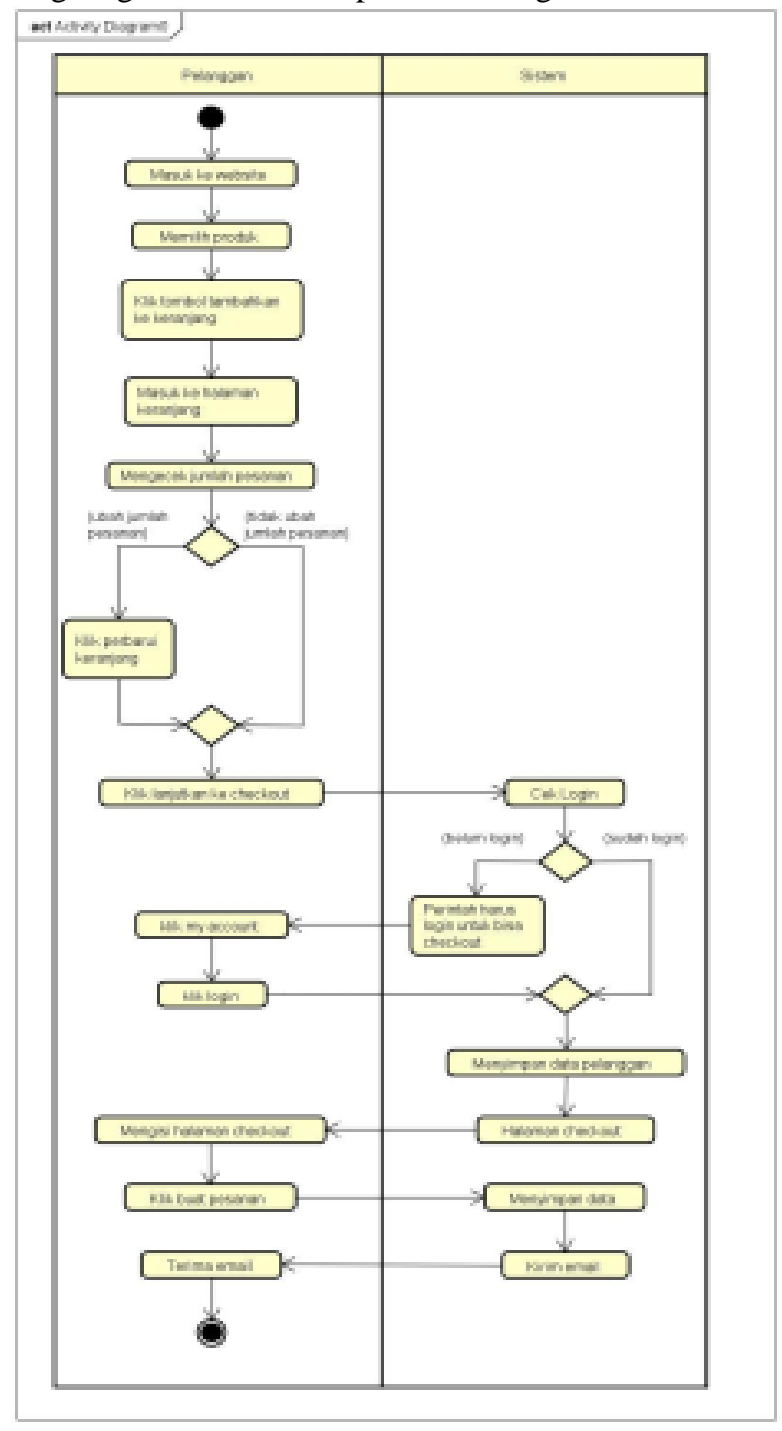

Gambar 4. Activity Diagram dalam Proses Pemesanan

\subsubsection{Proses Pembayaran}

Sebelum pelanggan melakukan pembayaran, pelanggan masuk ke menu checkout dan pelanggan harus mengisi nama dan alamat penerima, pemilihan kurir yang digunakan untuk pengiriman barang. Selanjutnya pelanggan mengklik buat pesanan. Maka selanjutnya sistem menyimpan data dan mengimkan email bukti pesanan, pelanggan menerima email bukti pesanan dan mengirimkan sejumlah uang sebesar bukti pesanan tersebut, pelanggan melakukan konfirmasi pembayaran dengan mengupload bukti transfer. Kemudian admin menerima email bukti pembayaran, lalu admin akan melakukan pengecekan uang pembayaran pelanggan serta merubah status pemesanan tersebut. Seperti yang ditampilkan pada gambar 5 . 
Halaman 232-241

available online at http://jom.fti.budiluhur.ac.id/index.php/IDEALIS/index

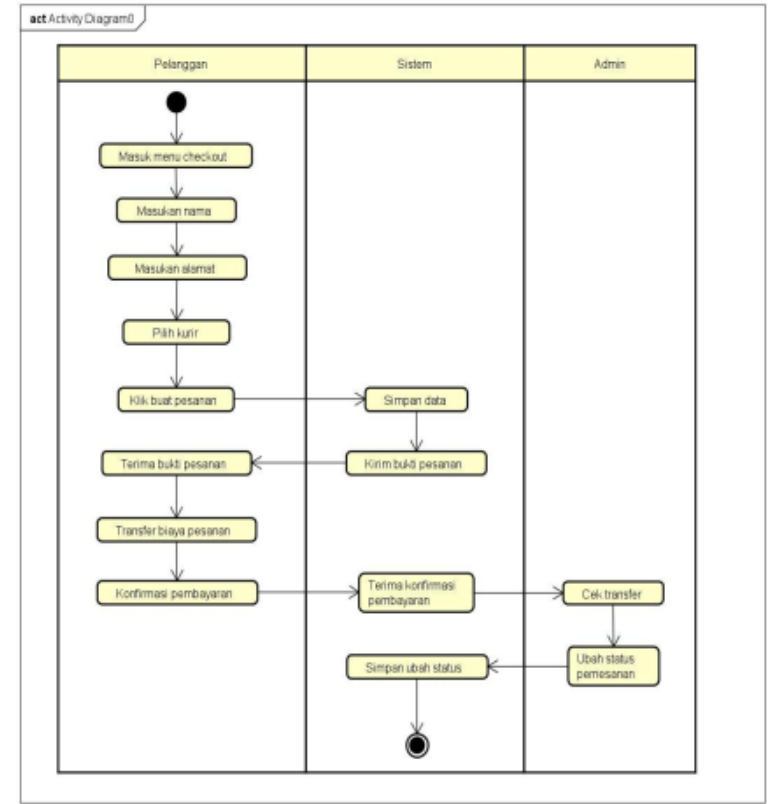

Gambar 5. Activity Diagram dalam Proses Pembayaran

\subsubsection{Proses Pengiriman}

Dalam proses ini, Admin melakukan pengemasan terhadap seluruh produk yang telah dipesan oleh pelanggan. Selanjutnya admin akan melakukan pencetakan surat jalan, melakukan pengiriman produk ke pihak ketika untuk pengiriman barang yang ditentukan pelanggan, kemudian kurir melakukan pencetakan dari data produk yang dibeli untuk dikirim. Berikutnya kurir mencetak resi sesuai nomor dan menyerahkan ke admin, lalu admin memasukkan nomor resi tercetak tersebut serta mengirimkannya ke pelanggan, seperti gambar 6 .

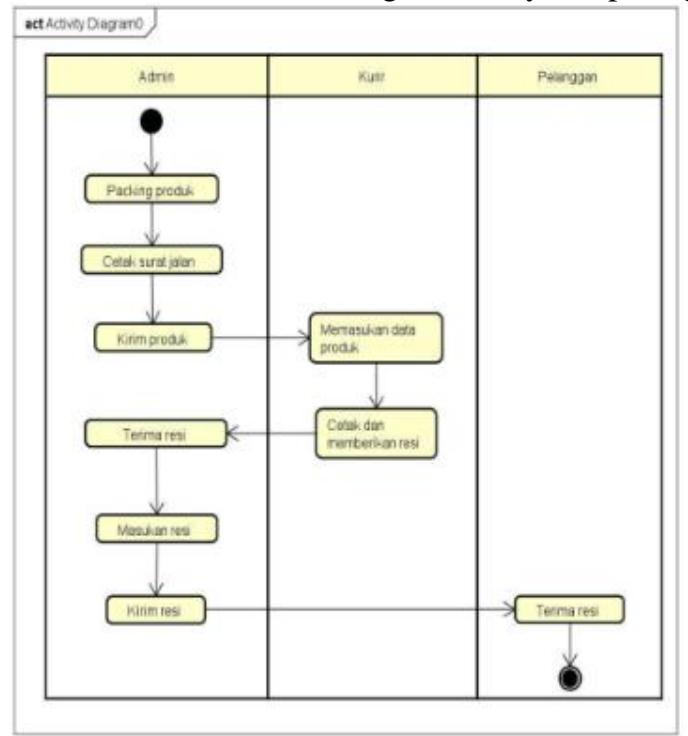

Gambar 6. Activity Diagram dalam Proses Pengiriman

\subsubsection{Proses Pembuatan Laporan}

Laporan yang dihasilkan adalah Laporan Penjualan, Laporan Pembayaran, Laporan Pembuatan Pesanan, Laporan Pengiriman, Laporan Rekapitulasi Kategori. Admin melakukan login halaman backend website, selanjutnya membuat rincian laporan penjualan pada menu Export Orders sehingga admin segera melihat laporan untuk setiap bulannya, seperti terlihat gambar 7 . 


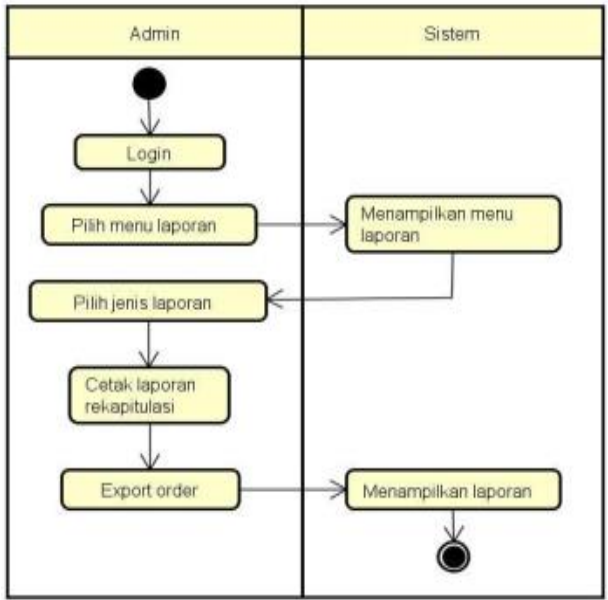

Gambar 7. Activity Diagram dalam proses Laporan Penjualan

\subsection{Aturan Bisnis}

Mengenai aturan bisnis yang berlaku pada Toko Second Original mencakup seluruh kegiatan perilaku bisnis yang berlangsung, yaitu: a. Pelanggan yang sudah membeli produk tidak dapat mengembalikan atau menukar produk tersebut. b. Pemesanan akan diproses apabila pelanggan telah melakukan pembayaran dan mengisi halaman konfirmasi pembayaran pada halaman website. c. Pelanggan dapat melakukan pembayaran melalui transfer bank. d. Pemesanan produk yang dilakukan pada jam 15.00 ke atas akan di proses pada hari berikutnya. e. Pemesanan produk pada hari Minggu atau libur nasional tetap akan diterima tetapi akan diproses di hari berikutnya. f. Pengiriman produk dilakukan pada sore hari setiap hari Senin - Sabtu, tidak akan ada pengiriman di hari Minggu serta libur nasional (tanggal merah). g. Pelanggan dapat melihat nomor resi apabila nomor resi telah di input oleh admin melalui email.

\subsection{Use Case Diagram}

a) Use Case Diagram dalam Master, Use Case ini yang terlihat pada gambar 8. Pada use case diagram master terlihat admin dapat mengentri kategori, berbagai produk dan jenis kurir. Sedangkan pelanggan dapat melakukan pendaftaran.

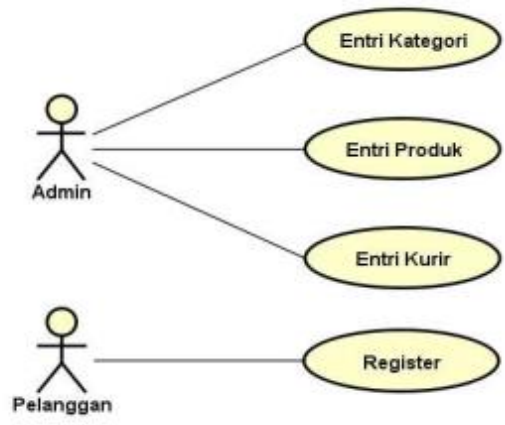

Gambar 8. Use Case Diagram dalam Master

b) Use Case Diagram dalam Transaksi, Use Case ini di gambar 9. menjelaskan Pada use case diagram mengenai kegiatan jual beli ini pelangan dapat mengentri pesanan, melihat keranjang, mengentri checkout, dan melakukan konfirmasi pembayaran. Sedangkan admin dapat melakukan entri resi pengiriman. 


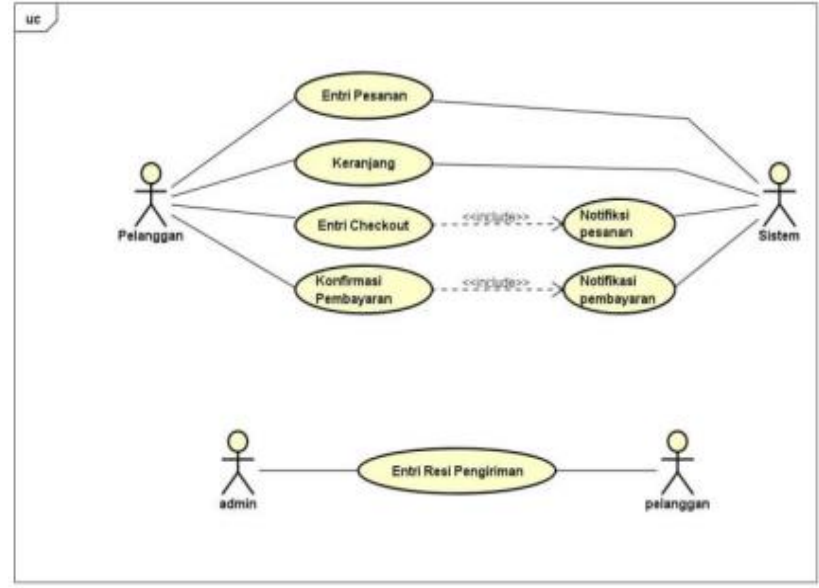

Gambar 9. Use Case Diagram dalam Transaksi

c) Use Case Diagram dalam Laporan, Use Case ini di gambar 10. Menjelaskan use case diagram mengenai pembuatan laporan dalam hal ini admin melakukan pencetakan laporan penjualan, cetak laporan pembayaran, cetak pemesanan, cetak pengiriman, cetak rekapitulasi penjualan.

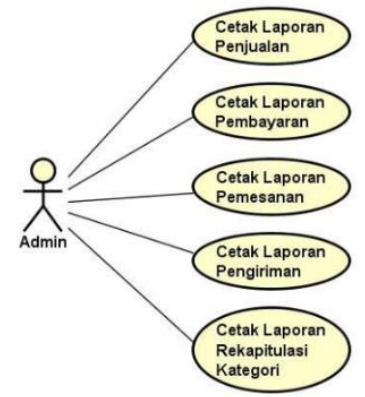

Gambar 10. Use Case Diagram dalam Laporan

\subsection{Search Engine Optimization (SEO)}

Strategi SEO dalam proses e-commerce di Toko Second Original. Melakukan strategi pencarian kata kunci yaitu SEO On Page, SEO On Page merupakan salah satu cara untuk meningkatkan akses halaman dan isi website agar dapat dilacak dan di index oleh mesin pencari dari dalam website itu sendiri. Artinya peningkatan akses website dilakukan dengan cara mengoptimasi struktur penyusun website. Dengan menggunakan salah satu plugin Yoast SEO.

a) Install Plugin dengan nama Yoast SEO. 1. Pada menu plugin pilih tambah baru. 2. Ketik Yoast SEO pada kolom pencarian.3. Klik pasang sekarang, lalu klik aktifkan plugin.

b) Meminta Kode Verifikasi Google dengan cara: 1. Masuk ke menu Yoast SEO lalu submenu umum. 2. Pada menu Webmaster Tools pilih Kode Verifikasi Google, kemudian klik link Google Search Console.3. Kemudian akan diarahkan ke halaman Webmaster Central. 4. Pilih HTML Tag, dan copy meta tag. 5. Paste HTML Tag pada kolom Kode Verifikasi Google. 6. Klik Simpan Perubahan pada Webmaster Tools.7. Klik Verify pada halaman Webmaster Central.

c) Setting XML Sitemaps.1. Akses ke halaman Google Search Console.2. Masukan URL website ke awalan URL. 3. Klik Terus, dan klik buka property.4. Pada menu umum di Yoast SEO, klik menu fitur kemudian klik peta situs XML, klik link tersebut.5. Masuk ke halaman XML Sitemap, 6. Copy URL XML Sitemap. 7. Paste ke menu Peta Situs di halaman Google Search Console, 8. Klik Kirim.

d) Optimalisasi Yoast SEO

1. Melakukan peningkatan akses di setiap halaman produk pada website, yaitu dengan menentukan banyak kunci pencarian Keyphrase, Judul SEO, Permalink, Deskripsi Meta dan isi Konten. 


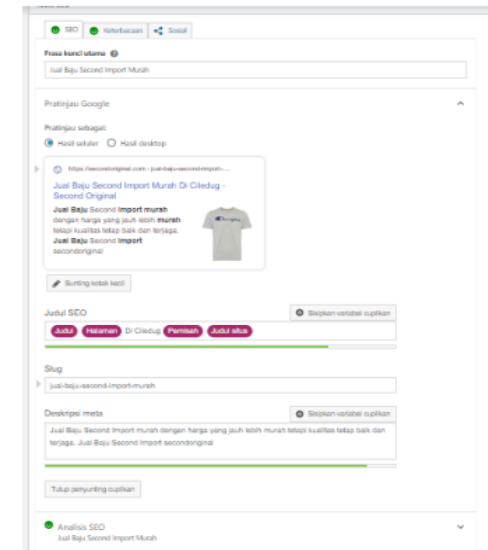

Gambar 12. Optimalisasi Yoast SEO Pada Halaman Produk

2. Melakukan Backlink ke halaman website di sosial media yang telah dimiliki, seperti Instagram, seperti terlihat pada gambar 13 .

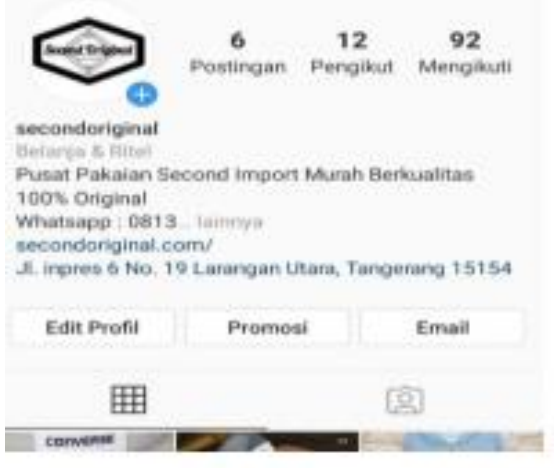

Gambar 13. Backlink Melalui Instagram

e) Submit Website ke Google Search Console

a. Klik inspeksi pada halaman Google Search Console.

b. Masukan URL setiap kali terjadi perubahan di setiap isi halaman website dan klik minta pengindeksan sehingga halaman di indeks oleh Google.

f) Hasil Pengujian

Setelah menerapkan langkah-langkah dan metode yang dilakukan dalam strategi SEO, terdapat beberapa keyword yang dioptimalisasikan pada setiap halaman website. Berikut adalah hasil penelusuran menggunakan Search Engine Google, dan kinerja yang diperoleh menggunakan Google Search Console, seperti yang terlihat pada gambar 14:

a. Hasil kinerja pada Google Search Console.

b. Hasil pencarian dengan keyword "BAJU SECOND IMPORT MURAH DI CILEDUG" tampil pada halaman ke 1 urutan ke 1. Pada tanggal 14 Mei 2020.

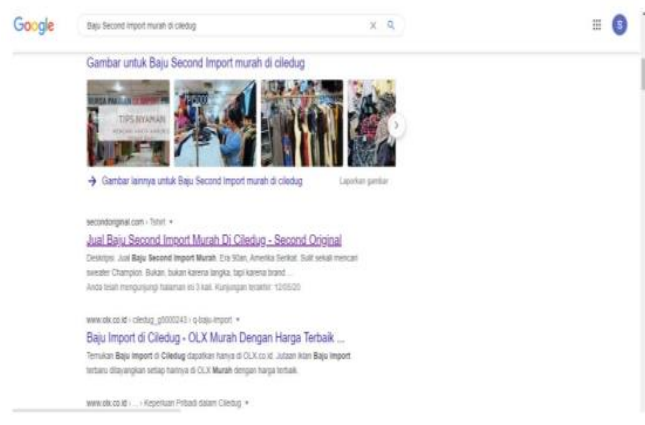

Gambar 14. Hasil Pencarian Key 


\subsection{Strategi Promosi}

Strategi pemasaran e-commerce yang diterapkan pada Toko Second Original yaitu menggunakan media sosial. Dengan pertimbangan menggunakan media sosial sebagai alat pemasaran dikarenakan kebanyakan dari target pasar aktif menggunakan media sosial dan jarak dari pemasaran menjadi semakin besar lagi.

Untuk strategi pemasaran dengan media sosial, Toko Second Original memilih Instagram. Nantinya akan diarahkan ke halaman website e-commerce Toko Second Original untuk melakukan transaksi pemesanan. Media sosial hanya sebatas tempat promosi dan interaksi customer dengan penjual [9][10]. Berikut strategi pemasaran menggunakan media sosial yaitu Instagram.

Berikut strategi pemasaran menggunakan Instagram.

a) Profil Bisnis, Keunggulan fitur Instagram bisnis disbanding profil Instagram biasa adalah pemilik akun dapat mempromosikan gambar atau video yang dipost berbentuk iklan pada aplikasi Instagram, kelengkapan informasi berupa nomor telepon, alamat, dan email, pemilik akun juga dapat melihat insight akun berdasarkan data statistik yang disediakan oleh Instagram.

b) Waktu Posting Produk, Waktu untuk memposting produk yaitu waktu dimana pengguna mengecek media sosial yaitu pagi saat akan mulai aktivitas, siang saat jam makan siang, dan malam saat sebelum tidur.

c) Strategi Penggunaan Hastag, Hastag menggunakan sebuah kunci dimana semua postingan yang menggunakan hastag akan di sorting menjadi satu pencarian. Fungsi dari hastag dalam pemasaran produk adalah meningkatkan peluang, karena banyak pengguna Instagram yang tidak mencari username toko melainkan menggunakan kata kunci berdasarkan hastag untuk mencari produk yang diinginkannya.

d) Pemanfaatan Instagram Story, Instagram story merupakan sebuah fasilitas yang dimiliki oleh Instagram yang menampilkan foto atau video dengan ukuran penuh satu layar, dan akan hilang setelah 24 jam. Dalam pemasaran produk menggunakan Instagram story, Toko Second Original menampilkan pemberitahuan postingan baru dan testimoni pembeli. Hal ini akan menarik pengunjung untuk mengunjungi profil akun.

e) Backlink Website Utama, Pemasaran produk menggunakan Instagram mempunyai tujuan yaitu pengunjung diarahkan ke halaman websiteutama. Pada Instagram, penempatan backlink utama terdapat pada bio akun Instagram.

f) Membuat Konten Menarik, Membuat konten Instagram yang menarik seperti give away produk, review produk, untuk menarik penggunaInstagram agar mengunjungi profil Toko Second Original.

\section{KESIMPULAN}

Berdasarkan pembahasan terhadap penerapan sistem perdagangan secara online dengan menggunakan pengaturan sistem yang terpusat di Toko Second Original, didapatlah beberapa titik kesimpulan dengan telah dilakukan penerapan sistem e-commerce, maka Toko Second Original tidak mengalami kesulitan dalam melakukan penjualan online untuk pelanggan yang berlokasi jauh dari Toko Second Original atau pelanggan yang tidak dapat dating ke toko. Website E-commerce pada Toko Second Original dapat melakukan promosi, melakukan pengolahan informasi, mengupdate produk terbaru, dan melayani customer dan dapat membantu customer sehingga dapat melakukan urutan proses pemesanan yang dilakukan dengan cara cepat dan membuat kemudahan bagi customer untuk mendapat informasi.

\section{DAFTAR PUSTAKA}

[1] W. M. Al-Salam, and D. Sudjanarti, "Desain Sistem Penjual Online Dengan Aplikasi CMS Prestashop Untuk Meningkatkan Pelayanan Pada Kenshop Batu", Jurnal Aplikasi Bisnis, vol. 4, no. 2, pp. 513-516, 2018.

[2] S. P. Suryanto, T. J. Pattiasina, and A. Soetarmono, "Perancangan dan Pengembangan Toko Online dengan Metode Interaction Flow Modeling Language (Studi Kasus Toko Winata)", Teknika, vol. 6, no. 1, pp. 7-18, 2017.

[3] S. Handayani, "Perancangan Sistem Informasi Penjualan Berbasis E-Commerce Studi Kasus Toko Kun Jakarta", Ilkom Jurnal Ilmiah, vol. 10, no. 2, pp. 182-189, 2018.

[4] S. M. Maulana, H. Susilo, and Riyadi, "Implementasi E-Commerce Sebagai Media Penjualan Online (Studi Kasus Pada Toko Pastbrik Kota Malang)", Jurnal Administrasi Bisnis, vol. 29, no. 1, pp. 1-9, 2015.

[5] S. M. Maulana, H. Susilo, and Riyadi, "Implementasi E-Commerce Sebagai Media Penjualan Online," J. Adm. Bisnis, vol. 29, no. 1, pp. $1-9,2015$.

[6] J. J. C. Y. Prawira, and T. I. Wardani, "Aplikasi CMS Wordpress Untuk Pembuatan Website Sebagai Media Promosi Di Wisata Keramik Dinoyo Kota Malang," Jurnal Aplikasi Bisnis, vol. 3, no.2, 2017.

[7] P. Osterwalder, Alexander and Yves, Business Model Generation A Handbook for Visionaries, Game Changers, and Challengers. Jakarta: Germany: Wiley, 2013.

[8] M. R. Adi Pratomo, E. Najwaini, A. Irawan, "Optimasi E-Commerce Dengan Penerapan Teknik SEO (Search Engine Optimization) Untuk Meningkatkan Penjualan pada UKM Nida Sasirangan”, Impact, vol. vol.1n no.1, pp. 35-45, 2018.

[9] A. P. Syahriani, T. Santoso, "Penerapan Sistem Informasi Web Penjualan Furniture", Simnasiptek, vol. 1, no.1, pp. 21-32, 2016.

[10] D., Dedi., E. T. B. Waluyu, and E. Setiawati, "Implementasi E-Commerce Dengan Menggunakan Metode B2C (Business to Customer)," SISFOTEK Global, vol. 6, no. 2, pp. 97-103, 2016. 